\title{
Strategic Lawsuit against Public Participation (SLAPP): A Legal-Based Threat to Freedom of Expression
}

\author{
Eko Riyadi*, Sahid Hadi** \\ DOI: https://doi.org/10.22304/pjih.v8n1.a7
}

Submitted: February 16, 2021| Accepted: April 4, 2021

\begin{abstract}
There are still many attempts to silence freedom of expression in Indonesia. One of the ways to silence the freedom of expression in Indonesia is Strategic Lawsuit against Public Participation (SLAPP). This study analyzed at least three SLAPP cases in Indonesia: (1) the case of Prita Mulyasari vs. the Omni International Alam Sutera Hospital in Tangerang; (2) the case of Budi Heryawan as known as Budi Pego; and (3) the case of Nur Alam vs. Basuki Wasis. This study proposed two questions. First, what is the pattern and portrait of SLAPP in Indonesia? Second, how is the analysis of human rights law on the use of SLAPP in Indonesia? This normative legal research is a case-based research. It uses the case, conceptual, and statutory approaches with qualitative data. The study concludes that SLAPP in Indonesia is used against people who fight for their rights, who defend their selves against human rights abuses committed by third parties, and to experts whose testimonies are used by a court. The representation shows that SLAPP is an effort to shift the problem from the real perpetrator to the victim. The SLAPP puts the victim in a high-risk position; drains and distracts the victim; and postpones problem-solving. Second, the SLAPP is an act that contradicts and/or has an adverse impact on freedom of expression. Courts must be present to affirm that the state takes sides to protect freedom of expression.
\end{abstract}

Keywords: courts, freedom of expression, SLAPP.

\section{Strategic Lawsuit Against Public Participation (SLAPP): Ancaman terhadap Kebebasan Berekspresi}

\begin{abstract}
Abstrak
Pembungkaman terhadap kebebasan berekspresi masih terjadi. Salah satunya melalui Strategic Lawsuit against Public Participation (SLAPP). Fenomena SLAPP terlacak, paling tidak, melalui tiga kasus yang dianalisis dalam penelitian ini, yaitu kasus Prita Mulyasari melawan Rumah Sakit Omni Internasional Alam Sutera Tangerang, kasus Budi Heryawan alias Budi Pego, dan Nur Alam melawan Basuki Wasis. Penelitian ini menjawab dua pertanyaan. Pertama, bagaimana pola dan potret penggunaan SLAPP di Indonesia? Kedua, bagaimana analisis hukum hak asasi manusia terhadap penggunaan SLAPP di Indonesia?
\end{abstract}

PADJADJARAN Journal of Law Vol. 8 Number 1 Year 2021 [ISSN 2460-1543] [ISSN 2442-9325]

* Lecturer at the Faculty of Law and Director of the Center for Human Rights Studies at the Islamic University of Indonesia (Universitas Islam Indonesia), Jl. Taman Siswa Nomor 158, Yogyakarta dan Gang Bakung No.517A, Jeruklegi, Pringgolayan, Banguntapan, Bantul, Daerah Istimewa Yogyakarta, S.H., M.H. (Universitas Islam Indonesia), eko.riyadi@uii.ac.id

** Researcher at the Center for Human Rights Studies of the Islamic University of Indonesia (PUSHAM UII), Gang Bakung No.517A, Jeruklegi, Pringgolayan, Banguntapan, Bantul, Yogyakarta Special Region, S.H. (Universitas Islam Indonesia), sahidhadi8@gmail.com 
Penelitian ini merupakan penelitian hukum normatif dalam bentuk analisis kasus. Pendekatan yang digunakan mengerucut pada pendekatan kasus, konseptual, dan perundang-undangan. Jenis datanya adalah data kualitatif. Kesimpulan dari penelitian ini adalah, pertama, SLAPP di Indonesia digunakan untuk melawan balik mereka yang memperjuangkan hak-haknya, mereka yang mempertahankan hak atas pelanggaran hak asasi manusia yang dilakukan pihak ketiga, dan mereka yang keterangan terkait keahliannya digunakan oleh pengadilan. Potret SLAPP di Indonesia menunjukkan, SLAPP merupakan upaya untuk menggeser persoalan dari pelaku kepada korban, SLAPP memposisikan korban dalam posisi penuh resiko, SLAPP menguras dan mengalihkan perhatian korban, dan SLAPP menunda pemecahan persoalan pokoknya. Kedua, SLAPP adalah tindakan yang bertentangan dan/atau melanggar kebebasan berekspresi. Pengadilan harus hadir untuk menegaskan bahwa negara berpihak dalam melindungi kebebasan berekspresi.

Kata Kunci: kebebasan berekspresi, pengadilan, SLAPP.

\section{A. Introduction}

Indonesia has an adequate normative commitment to freedom of expression. The commitment is traceable in Article 28, Article 28E paragraph (3), Article 28F, and Article $28 \mathrm{G}$ paragraph (1) of the 1945 Constitution of the Republic of Indonesia (the 1945 Constitution). All of the articles are clearly stated that, constitutionally, everyone has the right to express their thoughts and introduce their opinions, both in oral and written form. Everyone also has the right to communicate and to obtain information. The constitution also promises that everyone will not be disturbed when they try to seek, obtain, possess, store, process, and convey information through all types of media. To strengthen this commitment, the Constitution affirms the right of everyone to do or not to do something. The coherence of this guarantee leads to the constitutional recognition of the right to security and protection from the threat of fear for everyone. The purpose of this guarantee is none other than solely for the personal development of every Indonesian citizen and social environment.

This constitutional commitment lies on an Indonesian philosophical framework, the Pancasila, namely "Just and Civilized Humanity". It implies that normative guarantees for freedom of expression should indeed exist. This is because "Just and Civilized Humanity" mandates conformity between the nature and condition of the state and the essence of humanity. ${ }^{1}$ Based on the significance, "Just and Civilized Humanity" assigns freedom of expression as an independent variable (an influencing variable) and state performance as the dependent variable (the variable that is affected). Therefore, the state and individuals should not disturb the enjoyment and the exercise of freedom of expression, and human rights as a whole, for every single individual. 
The normative guarantee, unfortunately, has not been realized so that there are many problems in respecting and protecting freedom of expression. To say it in other words, there are still many practices to silence freedom of expression. At the macro level, global data on the Rule of Law Index shows that human rights guarantees in Indonesia in the last five years (2016 to 2020), have declined, compared to previous years. ${ }^{2}$ In this downward trend, aspects of freedom of expression need attention because guarantees for freedom of expression also shows the same trend. ${ }^{3}$ On a case basis, the threat to freedom of expression is at least represented, for instance, in: (1) the case of Nur Alam against Basuki Wasis; ${ }^{4}$ (2) the case of Prita Mulyasari against Omni International Hospital Alam Sutera Tangerang, ${ }^{5}$ and (3) the case of Budi Heryawan alias Budi Pego. ${ }^{6}$

The three aforementioned cases have similar elements. First, the parties who are being sued or charged are they who are defending or advocating their human rights or a public interest by exercising freedom of expression. Second, the civil suit or the criminal charge is filled after the defense and advocacy of the rights have been carried out. Third, all cases are resolved through court mechanisms. In legal terminology, such action is known as the Strategic Lawsuit against Public Participation (SLAPP). ${ }^{7}$ In the case of Nur Alam vs. Basuki Wasis, Nur Alam filed a lawsuit against Basuki Wasis in 2017. This lawsuit was filed because Alam felt aggrieved by a calculation of state losses compiled by Wasis. Previously, Wasis conveyed the calculation as an expert testimony at the trial for the corruption case of Alam. By this lawsuit, Alam expects material and immaterial damages from Wasis. ${ }^{8}$

2 In this case, World Justice Project indexing Indonesia's level of compliance with rule of law principles. Indonesia's compliance is stagnant, tends to be weak, in the last five years (2016-2020). In 2020, Indonesia scored 0.53 out of 1,00. World Justice Project, "Rule of Law Index 2020", Annual Report, p. 88. In 2019, Indonesia scored 0.52 out of 1,00. World Justice Project, "Rule of Law Index 2019", Annual Report, p. 87. In 2018 and 2017, Indonesia scored 0.52 out of 1,00. World Justice Project, "Rule of Law Index 2018-2017", Annual Report, p. 96. In 2016, Indonesia scored 0.52 out of 1,00. World Justice Project, "Rule of Law Index 2016", Annual Report, p. 96. In fact, in 2014, Indonesia scored 0.64 out of 1.00 and is classified as a country whose level of compliance with rule of law principles tends to be strong. World Justice Project, "Rule of Law Index 2014", Annual Report, p. 14. For human rights guarantees, Indonesia from 2016 to 2020 respectively scored $0.52,0.51,0.52$, and 0.52 out of 1.00 . The decline occurred in 2017-2018. In fact, in 2014, Indonesia obtained a score of 0.54 out of 1.00 .

3 For freedom of expression (one of the indicators for fundamental rights factor), Indonesia from 2016 to 2020

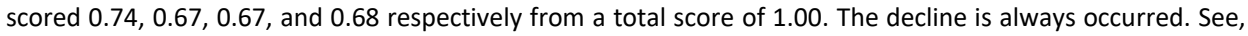
World Justice Project, "Rule of Law Index 2020", op.cit. See also, World Justice Project, "Rule of Law Index 2019", op.cit. See also, World Justice Project, "Rule of Law Index 2018-2017", op.cit. See also, World Justice Project, "Rule of Law Index 2016", op.cit.

4 Decision Number 47/Pdt.G/2018/PN.Cbi Decision Number 1269/PID.B/2009/PN.TNG., 882K/Pid.Sus/2010, 225PK/Pid.Sus/2011, and 300K/Pdt/2010. Decision Number 559/Pid.B/2017/PN.Byw and 174/PID/2018/PT.SBY.

In Southeast Asia, only the Philippines has a legal definition of SLAPP. See, Business \& Human Rights Resource Center, "Strategic Lawsuits against Public Participation: Southeast Asia cases \& recommendations for governments, business, \& civil society", Briefing Note, 2020. See also, Rule 1 Section 4 letter g AM No. 09-6-8SC regarding Rules of Procedure for Environmental Cases. See, footnote numbers 56-68.

8 Decision Number 47/Pdt.G/2018/PN.Cbi. 
The use of court mechanisms in SLAPP needs to be scrutinized, particularly in the context of freedom of expression. Referring to the factors of a state's compliance with the principles of rule of law according to the World Justice Project, ${ }^{9}$ criminal and civil justice are the two factors with the worst scores in Indonesia, side by side with the absence of corruption. In 2020, for instance, Indonesia's average score for compliance with the principles of the rule of law was 0.53 out of 1.00; the scores for criminal and civil justice were 0.39 and $0.46 .{ }^{10}$ In 2019, Indonesia's average score was 0.52 out of 1.00; the scores for criminal and civil justice were 0.37 and $0.44 .^{11}$ In 2017-2018, Indonesia's average score for compliance with the principles of the rule of law was 0.52 out of 1.00 ; the scores for criminal and civil justice were 0.35 and $0.45 .{ }^{12}$ These results show that the scores of criminal and civil justice in Indonesia have always been below average, at least in the last four years from 2017 to 2020.

Therefore, SLAPP should be read as a serious matter. Apart from the adequacy of normative guarantee for freedom of expression in Indonesia, the reason is also related to Indonesia's constitutional commitment to democracy. In this regard, SLAPP is like a black spot in the development of democracy in Indonesia. ${ }^{13}$

The fact that there is SLAPP practice in Indonesia triggers the formulation of two problems in this study. First, what is the pattern and portrait of the use of SLAPP in Indonesia? Second, how is the result of the analysis of human rights law on the use of the SLAPP in Indonesia? The answers to these questions converge on the analytical construction of the contradiction between SLAPP practices and freedom of expression.

The decision analysis in this research is classified as a normative legal research type. It is based on cases that have gone through judicial processes. The study use case, conceptual, and statutory approaches. The case-based approach was chosen because the object is concrete cases in which material facts have been translated into court decisions. The decisions are as follows.

1. Decision Number 1269/PID.B/2009/PN.TNG., 882K/Pid.Sus/2010, 225PK/Pid.Sus/2011, and 300K/Pdt/2010. These are the decisions of the case of Prita Mulyasari vs. the Omni International Hospital Alam Sutera, Tangerang.

2. Decision Number 559/Pid.B/2017/PN.Byw and 174/PID/2018/PT.SBY. These are the decisions of the case of Budi Heryawan also known as Budi Pego.

These factors are constraining on government powers, absence of corruption, open government, fundamental rights, order and security, order and security, regulatory enforcement, civil justice, and criminal justice.

10 World Justice Project, "Rule of Law Index 2020", op.cit.

11 World Justice Project, "Rule of Law Index 2019", op.cit.

12 World Justice Project, "Rule of Law Index 2017-2018", op.cit.

13 Sahid Hadi, "Bintang Emon is Getting SLAPP-ed", CNN Indonesia column", https://www.cnnindonesia.com/nasional/20200619113234-13-515121/bintang-emon-is-getting-slapp-ed, accessed on February 2021. 
3. Decision Number 47/Pdt.G/2018/PN.Cbi. This is the decision on the lawsuit submitted by Nur Alam to sue Basuki Wasis.

The concept-based approach was chosen because various doctrines and theories were needed to construct an analysis of the portrait and pattern of SLAPP in Indonesia and the contradiction between SLAPP and freedom of expression. The statute-based approach was chosen because of its qualifications to laws on freedom of expression, nationally, regionally, and internationally.

This study used qualitative data. The data are, first, primary legal materials, which at least consist of the 1945 Constitution of the Republic of Indonesia, Law Number 39 of 1999 on Human Rights (the Law on Human Rights), and the court decisions. Second, secondary data, which refers to books, scientific journals, research reports, annual reports, to news related to SLAPP and freedom of expression.

\section{B. Freedom of Expression: About Truth and Democracy}

Freedom of expression is one of human rights. Therefore, freedom of expression is often referred to as "the right to freedom of expression". ${ }^{14}$ It needs to be understood within the framework of human rights principles, in particular the principles of universality, indivisibility, interdependence, and interrelation. ${ }^{15}$ Given their nature as a human rights, everyone has equal freedom of expression, regardless of their religion, citizenship, language, ethnicity, political and anthropological identity, various disabilities, and sexual orientation. Freedom of expression is as important as, and inseparable from, other categories of human rights. The fulfillment of freedom of expression always depends on the fulfillment of other human rights.

Legal guarantees for freedom of expression exist in international, regional, and national human rights instruments. At the international level, guarantees are traceable to the Universal Declaration of Human Rights (UDHR), ${ }^{16}$ International Covenant on Civil and Political Rights (ICCPR), ${ }^{17}$ International Convention on the Elimination of All Forms of Racial Discrimination (ICERD), ${ }^{18}$ and the United Nations Convention on the Rights of the Child (CRC). ${ }^{19}$ At the regional level, the guarantees

14 Erica Howard, Freedom of Expression and Religious Hate Speech in Europe, New York: Routledge, 2018. See also, Claudio Grossman, "Challenges to Freedom of Expression within the Inter-American System: A Jurisprudential Analysis", Human Rights Quarterly, Vol. 34, Issue 2, 2012, pp. 361-403. See also, Stefan Kulk, Frederik Zuiderveen Borgesius, "Google Spain v. Gonzalez: Did the Court Forget about Freedom of Expression?", European Journal of Risk Regulation, Vol. 5, Issue 3, 2014, pp. 389-398.

15 For an explanation of these principles, see Eko Riyadi, Hukum Hak Asasi Manusia. Perspektif Internasional, Regional, dan Nasional, Jakarta: PT Raja Grafindo Persada, 2018, pp. 25-28.

Article 19 UDHR.

Article 19 ICCPR.

Article 5 ICERD.

Article 13 CRC. 
are adopted in the African Charter on Human and Peoples' Rights (ACHPR), ${ }^{20}$ the Resolution 169 on Repealing Criminal Defamation Law in Africa by the African Commission on Human and Peoples' Rights (Resolution 169), ${ }^{21}$ the European Convention for the Protection of Human Rights and Fundamental Freedoms $(E C H R){ }^{22}$ the American Convention on Human Rights (ACHR), ${ }^{23}$ and the ASEAN Human Rights Declaration (AHRD). At the national level, the guarantees are also contained in the 1945 Constitution, ${ }^{24}$ Law Number 9 of 1998 on the Freedom of Expressing Opinions in Public (the Law on Freedom of Expression), and Law Number 39 of 1999 on Human Rights (the Law on Human Rights). ${ }^{25}$

The guarantee is covered by a commitment that everyone is a free and rational human being. ${ }^{26}$ Freedom, with which each individual is born and without being given by anyone, makes everyone free to express thoughts and views and to hear and judge the thoughts and views of others. ${ }^{27}$ Ratio, a feature that distinguishes humans from other living creatures, in this context becomes a guide for everyone to judge right or wrong, in which the right is good for her/him and the wrong is bad for her/him, and also true or false.

Freedom and rationality, therefore, cannot be separated in understanding freedom of expression comprehensively because the freedom of expression in its essence works to reveal the truth. ${ }^{28}$ The most cited and well-known argument regarding the interconnectedness of freedom of expression and truth comes from Mill. ${ }^{29}$ Mill's premise, as explained by Moon, is that truth is most likely to be revealed and obtained when everyone can capture all information, even though some or many people consider the presented information is wrong. ${ }^{30}$ Mill strongly

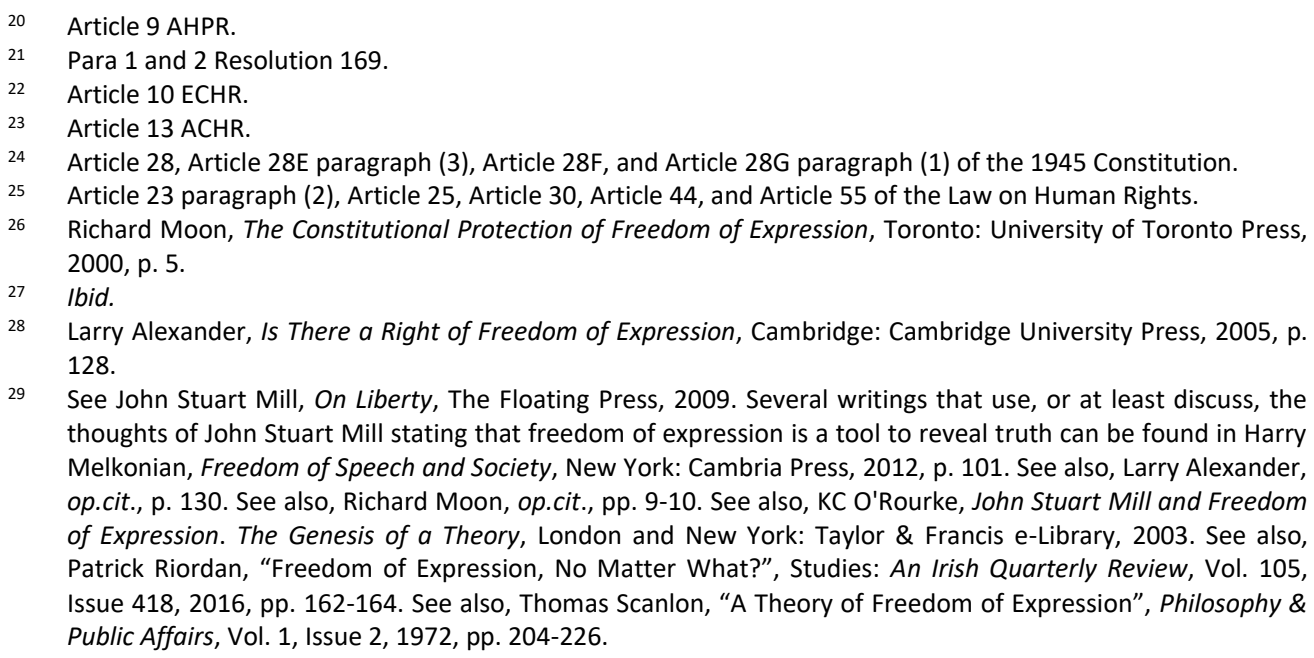

29 See John Stuart Mill, On Liberty, The Floating Press, 2009. Several writings that use, or at least discuss, the thoughts of John Stuart Mill stating that freedom of expression is a tool to reveal truth can be found in Harry Melkonian, Freedom of Speech and Society, New York: Cambria Press, 2012, p. 101. See also, Larry Alexander, op.cit., p. 130. See also, Richard Moon, op.cit., pp. 9-10. See also, KC O'Rourke, John Stuart Mill and Freedom of Expression. The Genesis of a Theory, London and New York: Taylor \& Francis e-Library, 2003. See also, Patrick Riordan, "Freedom of Expression, No Matter What?", Studies: An Irish Quarterly Review, Vol. 105, Issue 418, 2016, pp. 162-164. See also, Thomas Scanlon, “A Theory of Freedom of Expression”, Philosophy \& Public Affairs, Vol. 1, Issue 2, 1972, pp. 204-226.

30 Richard Moon, op.cit., p. 9. David O. Brink interprets, Mill believes that any information, views, and judgments may be true or false. Even if they are false, information, views, and judgments that are considered to be false may still contain some truth. Even though it is completely false, the presence of such misinformation, views, and misconceptions will prevent the right from becoming dogma. As dogma, these socalled information, views, and judgments lose their essence because the dialectical process stops. David O. Brink, "Mill's Deliberative Utilitarianism", Philosophy \& Public Affairs, Vol. 21, Issue 1, 1992, p. 86. Freedom of 
believes that dialectical, free, and open discussion and debate are essential in the discovery of supreme truth. Freedom of expression plays a role in such a framework. The absence of restrictions, including attempts to silence, on freedom of expression, including freedom of speech, will facilitate the process of finding the truth. ${ }^{31}$ It advances the goal of truth, Moon says. ${ }^{32}$

Many parties approve the truth-based argument. Barak, in his writing on freedom of expression and its boundaries, mentions it is the freedom of the individual... to illuminate the truth and falsity... to exchange opinion and views in a spirit of tolerance, without fear, with respect for the autonomy of every individual. ${ }^{33}$ Moon emphasizes that truth is a value of freedom of expression. ${ }^{34}$ Moon also states freedom of expression must be protected because it contributes to the public's recognition of truth or to the growth of public knowledge. ${ }^{35}$ In contrast to Moon, Tedford and Herbeck, as explained by Melkonian in his writing on freedom of expression and the society, assert that truth-based arguments, as justifications for freedom of expression, are philosophical reason. ${ }^{36}$

The two dimensions of humanity, freedom and ratio, do not only provide space for wrong or false information in the discourse of the freedom of expression. Freedom of expression, because of freedom and rationality, also has space for lie/falsehood at its stance. This is based on Kant's perspective on freedom of speech, as quoted by Varden, that such things as merely communicating his thoughts to them, telling or promising them something, whether what he says is true and sincere or untrue and insincere ... it is entirely up to them (the listener) whether they want to believe him or not. ${ }^{37}$ Varden also emphasizes that I choose to act on your suggestion is still entirely up to me... My choice to act on your word is beyond the reach of your words. ${ }^{38}$

The premises presented by Mill, Kant, and Varden show that the spirit of freedom of expression is centered around the liberal conviction that matters of moral choice must be left to the individual. ${ }^{39}$ Thus, first, based on freedom, everyone is free to introduce anything by words or actions, express thoughts and desires, and present right-or-wrong, true-or-false, and lie/falsehood information. However, second, everyone also has rational reasoning abilities, as well as

expression for Mill is not only about the process of exchanging information that is true or false and right or wrong, so he believes that restrictions on freedom of expression are "not a question of the truth of doctrine, but of their usefulness." John Stuart Mill, op.cit., pp. 38-39.

31 Read John Stuart Mill, op.cit., pp. 28-40. See also, Harry Melkonian, op.cit.

32 Richard Moon, op.cit., p. 10.

33 Aharon Barak, "Freedom of Expression and Its Limitation", Qasher, No.8, November 1990, p. 4e.

34 Richard Moon, op.cit., p. 8.

35 Ibid.

36 Harry Melkonian, op.cit., pp. 100-101.

37 Helga Varden, "A Kantian Conception of Free Speech", in Deirdre Golash (Ed.), Freedom of Expression in a Diverse World, New York: Springer, 2010, p. 42.

$38 \quad$ Ibid.

39 Helen Fenwick, Civil Liberties and Human Rights, Fourth Edition, Oxon: Routledge-Cavendish, 2007, p. 301. 
experiences, which guide them to assess available and provided information. Thus, everyone can question every statement and action. ${ }^{40}$

Freedom of expression, apart from working to uncover the truth, is also an important element of democracy in connection with public interest discourse. ${ }^{41}$ As Forsskal campaigned in 1769, every individual must be free to express his thoughts on public issues because every individual has the right to contribute to the public good. Forsskal emphasizes, where this is lacking, liberty is not worth its name. ${ }^{42}$ La Rue interprets Forsskal's campaign in an interesting way, in which the main premise of Rue's interpretation is that to achieve the common good, a democratic state requires the participation of all elements of the people and that this meant they should be well-informed in all matters related to the public interest. ${ }^{43}$ Also, at the operational level, the quality of democracy of a state today is determined by the good or bad guarantees of freedom of expression, even though freedom of expression is not identical with democracy. ${ }^{44}$

Government from, by, and for the people is a commitment to democracy. First, "from the people" mandates that everyone have equal opportunity to take part in government. This element is also committed to the sovereignty of each person to elect and determine the leader. At a more abstract level, "from the people" becomes the foundational basis for the implementation of government based on general ethical will (volonte generale). Second, "by the people" signifies a fully democratic commitment to public participation. Therefore, the principle allows everyone, in any way, to be legally involved in the implementation of government. Third, "for the people" refers to services, policies, and legislation products that the government presents and provides to the people. Based on the significance, the people who are well-informed becomes a key point. Running a government based on these three principles is a skill, not just a random intuition. Therefore, freedom of expression also works to create well-informed people.

A complete understanding of freedom of expression provides an interpretive framework of the importance of the category of rights. Philosophically, freedom of expression leads humankind to the supreme truth. It helps the public interest to be adequately abstracted. Freedom of expression politically is also a basic prerequisite for democratic government. Freedom of expression can ... be regarded as a catalyst

$40 \quad$ Harry Melkonian, op.cit., pp. 46-47.

41 KC O'Rourke even refers to freedom of expression as "the most basic traits of democracy. "KC O'Rourke, John Stuart Mill and Freedom of Expression. The Genesis of a Theory, London and New York: Taylor \& Francis eLibrary, 2003, p. 70.

42 Peter Forsskal, "Thoughts on Civil Liberty," http://www.peterforsskal.com/thetext.html, accessed on February 2021.

43 Frank La Rue, "Peter Forsskal - A Forefather of Freedom of Expression", in Ulla Carlsson, David Goldberg, The Legacy of Peter Forsskal. 250 Years of Freedom of Expression, Sweden: Nordicom, 2017, p. 96.

44 This linkage can be seen, for example, in The Economist, "Democracy Index 2019. A year of democratic seatbacks and popular protest", A Report by The Economist Intelligence Unit, point 46, p. 62. Cf Arnold H. Loewy, "Freedom of Speech as a Product of Democracy", University of Richmond Law Review, Vol. 27, Issue 3, 1993. 
which keeps society on the road to progress and cultivation..$^{45}$ Given its nature as a human right, freedom of expression is essential to human dignity. ${ }^{46}$

The above interpretive framework is sufficient to answer the question for what reasons must freedom of expression is respected ${ }^{47}$ However, in reality, some people face and deal with silencing when exercising their freedom of expression. One of these attempts, concretely, is SLAPP. ${ }^{48}$

\section{Patterns and Portraits of SLAPP in Indonesia: A Study of Court Decisions}

Several cases in Indonesia show a trend of increasing use of SLAPP as a tool of countering public participation and silencing freedom of expression. SLAPP is also used against people who defend or fight for their human rights. This study took the cases that happened to Prita Mulyasari, Heri Budiawan also known as Budi Pego, and Basuki Wasis.

The three aforementioned cases reflect three patterns of confrontation to people defending their human rights. The first pattern is the use of SLAPP to people defending or fighting for their human rights. The second pattern is the use of SLAPP to people defending their rights against human rights violations committed by the state or human rights abuses committed by third party such as corporation. The third pattern is the use of SLAPP to experts whose testimony is used by a court.

The first pattern is found in the Prita Mulyasari case. Mulyasari is a patient who complained about health services from the Omni International Hospital, Alam Sutera, Tangerang in 2008. The complaint was sent to the hospital management, but she did not receive an adequate response. Therefore, Mulyasari sent the complaint to a number of his colleagues via email. The hospital did not accept Mulyasari's actions. The hospital then took issue with Mulyasari's actions in two ways, namely the use of criminal charge and civil lawsuit mechanisms. Mulyasari has criminally complained of an alternative charge of violating the use of electronic media, defamation, or offense in writing. ${ }^{49}$ In civil lawsuit, Mulyasari was sued for having committed tort with a claim for compensation of one trillion rupiahs (IDR $1,000,000,000,000) .^{50}$

$45 \quad$ KC O'Rourke, op.cit., p. 46.

46 Harry Melkonian, op.cit., p. 101.

47 Respect is understood exactly the same as the meaning of the obligation to respect in the realm of human rights, namely the obligation not to interfere with the exercise and enjoyment of freedom of expression. Eko Riyadi, op.cit., p. 71.

48 Penelope Canan and George W. Pring introduced the term SLAPP. Their study was conducted based on the observation that there is an increase in the incidence of labeling environmental protection activists and organizations as defendants. Canan and Pring conducted their research by identifying one hundred cases in the United States and Columbia. See, Penelope Canan and George W. Pring, "Studying Strategic Lawsuit against Public Participation: Mixing Qualitative and Quantitative Approaches", Law \& Society Review, Vol. 22, Issue 2, 1988, pp. 387-388. See also. Sahid Hadi, "Bintang Emon is Getting SLAPP-ed", Column, https://www.cnnindonesia.com/nasional/20200619113234-13-515121/bintang-emon-is-getting-slapp-ed, accessed on February 2021.

49 Supreme Court Decisions Number 822K/Pid.Sus/2010 and Number 225PK/Pid.Sus/2011.

50 Supreme Court Decision Number 300K/Pdt/2010. 
The court stated that Mulyasari was not proven to have committed a criminal act, whether it was a violation of the use of electronic media, written defamation, or offense. There are two main reasons for the panel of judges, in the Peninjauan Kembali, an extraordinary legal effort, in the decision. First, the complaint expressed by Mulyasari is not a falsehood, really felt, and has no purpose to defame. Mulyasari also made a complaint through her email and it was also sent to her friends' email. This action is a complaint that cannot be qualified as a criminal act of defamation through electronic means. Second, at the time the indictment was made, the government regulation as a derivative of the law had not been enacted. Therefore, the use of Law Number 11 of 2008 on Electronic Information and Transactions is an act of violating the principle of legality.

Mulyasari was also declared not to have committed tort. The panel of judges made an important consideration that disclosing what was experienced was not a tort, but only a complaint. Emails sent to friends are personal complaints based on events that she has experienced.

The second pattern referes to the case of Heri Budiawan also known as Budi Pego. Budi Pego is a resident who expressed his disapproval of the operation of a gold mining company in the Mount Salah area of Banyuwangi, East Java. He was charged with spreading the teachings of communism and Marxism-Leninism by allowing an anonymous person to draw a "palu arit" on a banner rejecting mining activities. The banner was installed on Jalan Raya Pancer, Sumberagung Village, Pesanggaran District, Banyuwangi Regency. ${ }^{51}$ For the action he was accused of, Budi Pego was found legally and convincingly proven to have committed crimes against state security and sentenced to ten months in prison. ${ }^{52}$

The third pattern occurred in the case of Basuki Wasis. Wasis is a lecturer and an expert in environmental science. He was invited by the Corruption Eradication Commission (KPK-Komisi Pemberantasan Korupsi) to help to explain environmental damage and losses caused by the operation of a company. The company gained a permit from Nur Alam, the Governor of North Sulawesi. ${ }^{53}$ According to his expertise, Basuki Wasis explained that the operation of PT Anugerah Harisma Barakah had caused environmental damage in the Southeast Sulawesi region.

Wasis' statement was used by the panel of judges in calculating state losses caused by environmental damage. Alam used a civil law mechanism, tort lawsuit, later to sue Wasis. Wasis was suspected of having committed tort by providing information that was different from the testimony of other experts presented at the previous criminal trial where the decision has been legally binding. Alam was sentenced to twelve years in prison and a fine of IDR 1 billion and an additional penalty of IDR $2,781,000,000$,- for the trial of a corruption case. ${ }^{54}$

Decision Number 559/Pid. B/2017/Pid. Byw.

This decision was strengthened by the Surabaya High Court Decision Number 174/PID/2018/PT SBY.

Decision Number 47/Pdt.G/2018/PN.Cbi.

Decision Number 123/Pid.Sus-TPK/017/PN Jkt.Pst. 
Based on this logic, the Plaintiff filed a civil lawsuit at the Cibinong District Court with a request that the judge declared that the Defendant was found guilty of violating the law, and ordered the Defendant to pay material loss of IDR $1,472,723,024,-$ and immaterial loss of IDR 3,000,000,000,000,--

The panel of judges rejected Alam's lawsuit. There are important considerations in this decision. The expert's testimony will change to a court legal opinion when it has been adopted by the panel of judges. ${ }^{55}$ The expert's statement will only become an academic opinion if the judge in the consideration of the verdict does not adopt the statement. If there are objections to an expert's academic opinion, then the action to fight it is to present another academic study before the trial. The judge will determine the opinion used as a legal consideration. When the expert's statement has been adopted into the consideration of the decision, then it has become the legal opinion of the judge. To fill a criminal charge on expert testimony that has been submitted before the court, let alone already adopted in a decision, is tantamount to contesting a judge's decision. If this is the case, then all judges will potentially be sued for their decisions that are detrimental to the convict. Then, the law enforcement order will fall apart.

The patterns become a further means of making portraits on the use of SLAPP. SLAPP is defined as a meritless legal action brought against individuals or groups with the intention of silencing the opponents, or at least ... diverting their resources. ${ }^{56}$ Its main premise is a lawsuit or litigation directed against citizens, both individually and in groups, for their advocacy on social and public issues. ${ }^{57} \mathrm{~A}$ litigation mechanism is classified as SLAPP when a public or private entity uses court facilities or legal mechanisms to obstruct, or to retaliate against, people exercising their freedom of expression in a way that threaten the entities' interests. ${ }^{58}$

Canan and Pring reveal that SLAPP always begins with the exercise/distribution of expressions, usually in the form of complaints or criticisms in writing or in the form of actions, or advocacy on social, humanitarian, or public issues. The judicial mechanisms are used by the plaintiffs/complainants/appellants to silence the targeted person. ${ }^{59}$ This also shows the difference between SLAPP and lawsuits or litigations in general, where the general lawsuit or litigations aim to get a legal and

\footnotetext{
Decision Number 47/Pdt.G/2018/PN.Cbi., p. 87.

Lauren McBrayer, "The DirecTV Cases: Applying anti-SLAPP Laws to Copyright Protection Cease-and-Desist Letters", Berkeley Technology Law Journal, Vol. 20, Issue 2, 2005, p. 608.

57 Penelope Canan, George W. Pring, op.cit., p. 385.

58 Lauren McBrayer, op.cit., p. 607. See also, J. Reid Mowrer, "Protection of the Public Against Litigious Suits ("PPALS"): Using 1993 Federal Rule 11 to Turn SLAPPs Around", Natural Resources Journal, Vol. 38, Issue 3, 1998, p. 468.

$59 \quad$ Penelope Canan, George W. Pring, op.cit., p. 386.
} 
fair remedy. ${ }^{60}$ Saner asserts in this case, given these objectives, the typical SLAPP suit occurs after a defendant has spoken out against or criticized a plaintiff. ${ }^{61}$

Barker states that the motives behind SLAPP were often wrong. ${ }^{62}$ The reason is, since the beginning, SLAPP was not intended to obtain remedy due to a substantial loss of rights. ${ }^{63}$ It is simply to threaten, intimidate, and silence certain expressions. ${ }^{64}$ The same conclusion came from Pring that the main motivation of the SLAPP mechanism was to stop someone from exercising their freedom of expression or punishing someone for their actions based on freedom of expression. ${ }^{65}$ Wilson also emphasizes that SLAPP was conducted for reasons of reducing the spirit of advocacy from critics/opponents. ${ }^{66}$ McBrayer provides the same affirmation that SLAPP lawsuits are not filed to vindicate legitimate legal claims, but rather to intimidate and discourage opposition from their targets. ${ }^{67}$ In this case, Cosentino specifically mentions that there are four motivations behind the use of SLAPP: (1) retaliation for successful opposition; (2) discouraging future opposition; (3) intimidation; and (4) a strategic tool in a political battle. ${ }^{68}$

The three cases indicate that SLAPP has been used to silence and intimidate others. The case that happened to Budi Heryawan is a clear example of the use of law to silence groups who rejected the local government policy that allowed mining companies to operate. In other cases, SLAPP was used to intimidate another party. The use of the criminal mechanism against Prita Mulyasari is an act that has seriously disturbed the comfort and safety of life. In the same way, Basuki Wasis experienced a civil lawsuit. The lawsuit was an attempt to personalize his professional actions as if it was Wasis' personal actions. In fact, Basuki Wasis was invited by a law enforcement agency, the KPK.

Based on Cosentino's idea, there are four portraits of SLAPP cases. First, SLAPP transforms the position of the parties because the lawsuit or demands that are filed change the issues in question. The substance of the problem that was initially attached to the behavior of the plaintiff/complainant/ appellant, shifted to the litigation activities of the targeted person. Second, SLAPP increases the risks

60 Katelyn E. Saner, "Getting SLAPP-ed in Federal Court: Applying State Anti-SLAPP Special Motions to Dismiss in Federal Court After 'Shady Grove'", Duke Law Journal, Vol. 63, Issue 3, 2013, p. 787.

61 Ibid, p. 788. See also, Penelope Canan, George W. Pring, pp. 385-386.

62 John C. Barker, "Common-Law and Statutory Solutions to the Problem of SLAPPs", Loyola of Los Angeles Law Review, Vol. 26, Issue 395, 1993, p. 403.

63 Paul D. Wilson, "Of Sexy Phone Calls and Well-Aimed Goal Balls: Anti-SLAPP Statutes in Recent Land-Use Damages Litigation", The Urban Lawyer, Vol. 36, Issue 2, 2004, p. 375.

64 J. Reid Mowrer, op.cit., p. 487. See also, Katelyn E. Saner, op.cit., pp. 788-789. See also, Robert D. Richards, "A SLAPP in the Facebook: Assessing the Impact of SLAPP on Social Networks, Blogs and Consumer Gripe Sites", DePaul Journal of Art, Technology \& Intellectual Property Law, Vol. 21, Issue 2, 2011 , p. 226.

65 George W. Pring, "SLAPPs: Strategic Lawsuits against Public Participation", Pace Environmental Law Review, Vol. 7, Issue 1, 1989, p. 6.

66 Paul D. Wilson, op.cit.

67 Lauren McBrayer, op.cit., p. 609.

68 Victor J. Cosentino, "Strategic Lawsuits against Public Participation: An Analysis of the Solutions", California Western Law Review, Vol. 27, Issue 2, 1991, p. 402. 
involved. The SLAPP not only punished the target's freedom of expression at the time he was proposed but also other rights because the target had to spend substantial time and money on carrying out judicial procedures. ${ }^{69}$ Third, SLAPP can distract its victims. Fourth, SLAPP postponed solving problems on the main issues that were voiced..$^{70}$ In addition, Canan and Pring also revealed that SLAPP in fact intimidated victims and made them think twice to do advocacy. ${ }^{71}$

In the case of Prita Mulyasari, the real problem lies in the service, both medical and complaint services, of the Hospital. However, in this case, the problem shifted to be Mulyasari's problem. In the context of human rights, as stipulated in the second pillar of the United Nations Guiding Principles on Business and Human Rights (UNGP), companies get a responsibility to respect human rights. In the case of Budi Heryawan, the real problem lies on the non-participatory operating license of a mining company. Residents were not consulted previously about the permit granting process. However, the problem turned to the alleged violation against the law by Budi Heryawan. In the last case, the real problem occurs in acts of corruption that have been legally ruled by the court. However, the problem shifted to the alleged illegal act committed by Basuki Wasis.

These three cases also show a situation, that the defendant and/or the suspect must spend time, energy, and position themselves in a high-risk situation, both security and economic risks. Prita Mulyasari and Budi Heryawan had to be detained, which, of course, greatly disturbed their psychological and physical conditions. Prita Mulyasari and Basuki Wasis must be cautious if the court accepts a lawsuit for a very large amount of money. They have to prepare the worst risk to pay the huge fine.

The SLAPP cases change the position of victims as if they are perpetrators. In the cases of Prita Mulyasari and Budi Heryawan, they were both victims of the hospital's health services and the company's operation, which would interfere the right to health and also a good and healthy environment. However, in the judicial process, they had to sit on the hot chair of the defendants on the charges of committing a criminal act. The cases also show that the main problems that occurred were not resolved. The patient's complaint case was not responded to and was not resolved by the Hospital. Cases of complaints about environmental pollution and violations of permits were also not resolved. All energies had been focused on the judicial process where people who defend or fight for their human rights have to face a long and winding legal process.

69 Colin Quinlan, "Erie and The First Amendment: State Anti-Slapp Laws In Federal Court After Shady Grove", Columbia Law Review, Vol. 114, No. 2, 2011, p. 370.

70 Victor J. Cosentino, "Strategic Lawsuits against Public Participation: An Analysis of the Solutions", California Western Law Review, Vol. 27, Issue 2, 1991, p. 403.

71 Penelope Canan, George W. Pring, op.cit., pp. 392-393. See also, Colin Quinlan, op.cit. 


\section{SLAPP is a Threat to Freedom of Expression}

Considering Mill, Kant, and Varden's ideas, freedom of expression is a fundamental right inherent in every human being. ${ }^{72}$ Therefore, freedom of expression encompasses, first, the freedom of everyone to convey and express thoughts and information. Second, that everyone has the capacity for rational reasoning that guide them to asses whether a thought and information is right or wrong, true or false, and lie/falsehood. ${ }^{73}$ This idea can also be found in human rights instruments, particularly those related to civil and political rights. Normative provisions on freedom of expression can be found in national and international documents. At the very least, these provisions are as follows.

Table 1. Laws in Indonesia Governing Freedom of Expression

\begin{tabular}{|c|c|c|c|}
\hline No. & Regulation & Article & Provision \\
\hline \multirow[t]{4}{*}{1.} & \multirow[t]{4}{*}{$\begin{array}{l}\text { The } 1945 \text { Constitution of } \\
\text { the Republic of Indonesia }\end{array}$} & Article 28 & $\begin{array}{l}\text { Freedom ... expressing thoughts } \\
\text { orally and in writing, etc. is } \\
\text { stipulated by laws. }\end{array}$ \\
\hline & & $\begin{array}{l}\text { Article } 28 \mathrm{E} \\
\text { paragraph (3) }\end{array}$ & $\begin{array}{l}\text { Everyone has the right to freedom } \\
\text {... to express an opinion. }\end{array}$ \\
\hline & & Article $28 \mathrm{~F}$ & $\begin{array}{l}\text { Everyone has the right to } \\
\text { communicate and obtain } \\
\text { information to develop their } \\
\text { personal and social environment, } \\
\text { as well as the right to seek, obtain, } \\
\text { possess, store, process and convey } \\
\text { information using all available } \\
\text { channels. }\end{array}$ \\
\hline & & $\begin{array}{l}\text { Article } 28 \mathrm{G} \\
\text { paragraph (1) }\end{array}$ & $\begin{array}{l}\text { Everyone has the right to personal } \\
\text { protection ... and the right to feel } \\
\text { secure and protection from the } \\
\text { threat of fear to do or not do } \\
\text { something, which is a human right. }\end{array}$ \\
\hline \multirow[t]{2}{*}{2.} & \multirow[t]{2}{*}{$\begin{array}{l}\text { Law Number } 39 \text { of } 1999 \\
\text { on Human Rights }\end{array}$} & $\begin{array}{l}\text { Article } 14 \\
\text { paragraph (1) }\end{array}$ & $\begin{array}{l}\text { Everyone has the right to } \\
\text { communicate and obtain } \\
\text { information to develop his or her } \\
\text { personal and social environment. }\end{array}$ \\
\hline & & $\begin{array}{l}\text { Article } 14 \\
\text { paragraph (2) }\end{array}$ & $\begin{array}{l}\text { Everyone has the right to seek, } \\
\text { obtain, own, store, process, and } \\
\text { convey information using all } \\
\text { available means. }\end{array}$ \\
\hline
\end{tabular}

Helen Fenwick, op. cit., p. 301.

Harry Melkonian, op.cit., pp. 46-47. 


\begin{tabular}{|c|c|c|c|}
\hline & & $\begin{array}{l}\text { Article } 23 \\
\text { paragraph (2) }\end{array}$ & $\begin{array}{l}\text { Everyone is free to have, issue, } \\
\text { and disseminate opinions } \\
\text { according to their conscience, } \\
\text { orally and/or in writing through } \\
\text { print and electronic media. }\end{array}$ \\
\hline & & Article 25 & $\begin{array}{l}\text { Everyone has the right to express } \\
\text { his or her opinion in public. }\end{array}$ \\
\hline & & Article 30 & $\begin{array}{l}\text { Everyone has the right to a sense } \\
\text { of security and security and } \\
\text { protection against the threat of } \\
\text { fear of doing or not doing } \\
\text { something. }\end{array}$ \\
\hline \multirow[t]{2}{*}{3.} & \multirow[t]{2}{*}{$\begin{array}{l}\text { Law Number } 9 \text { of } 1998 \\
\text { on the Freedom of } \\
\text { Expressing Opinions in } \\
\text { Public }\end{array}$} & $\begin{array}{l}\text { Article } 2 \\
\text { paragraph (1) }\end{array}$ & $\begin{array}{l}\text { Every citizen, individually or in } \\
\text { groups, is free to express his } \\
\text { opinion as a manifestation of } \\
\text { democratic rights and } \\
\text { responsibilities in the life of } \\
\text { society, nation, and state. }\end{array}$ \\
\hline & & Article 5 & $\begin{array}{l}\text { Citizens expressing opinions in } \\
\text { public have the right to (a) express } \\
\text { their thoughts freely and (b) } \\
\text { obtain legal protection. }\end{array}$ \\
\hline 4. & $\begin{array}{l}\text { Universal Declaration of } \\
\text { Human Rights }\end{array}$ & Article 19 & $\begin{array}{l}\text { Everyone has the right to freedom } \\
\text { of opinion and expression; this } \\
\text { right includes freedom to hold } \\
\text { opinions without interference and } \\
\text { to seek, receive and impart } \\
\text { information and ideas through any } \\
\text { media and regardless of frontiers. }\end{array}$ \\
\hline \multirow[t]{2}{*}{5.} & \multirow{2}{*}{$\begin{array}{l}\text { International Covenant } \\
\text { on Civil and Political } \\
\text { Rights (ICCPR), which has } \\
\text { been ratified by the } \\
\text { Indonesian government } \\
\text { by the Law Number } 12 \text { of } \\
2005 \text { on the Ratification } \\
\text { of the ICCPR }\end{array}$} & $\begin{array}{l}\text { Article } 19 \\
\text { paragraph (1) }\end{array}$ & $\begin{array}{l}\text { Everyone shall have the right to } \\
\text { hold opinions without } \\
\text { interference. }\end{array}$ \\
\hline & & $\begin{array}{l}\text { Article } 19 \\
\text { paragraph (2) }\end{array}$ & $\begin{array}{l}\text { Everyone shall have the right to } \\
\text { freedom of expression; this right } \\
\text { shall include freedom to seek, } \\
\text { receive, and impart information } \\
\text { and ideas of all kinds, regardless of } \\
\text { frontiers either orally, in writing, } \\
\text { or in print, in the form of art, or in } \\
\text { any other media of her or his } \\
\text { choice. }\end{array}$ \\
\hline
\end{tabular}

The above norms provide four important provisions. First, freedom of opinion and expression is an important part of democracy. Democracy is a social system where everyone has an open space to be involved in determining public policy. Freedom 
of expression is a way to ensure that public space is discussed. There is no democracy without freedom of expression. Thus, the rule of law must put protection on freedom of expression as a way to ensure that the government runs fairly and is based on respect for human rights. Second, freedom of expression is a building block for self-development. This can be seen in particular in the Law on Human Rights, which places freedom of expression in Part Three, the Right to SelfDevelopment. The more the people of a state developed economically, knowledgeably, and politically, the more space must be given to freedom of expression. Third, freedom of expression is always close to freedom of opinion. Freedom of expression encompasses freedom to convey thoughts. In this context, freedom of opinion is the inner condition (forum internum/mens rea) of a person to have thoughts, opinions, or ideas in accordance with beliefs. In the meantime, freedom of expression is an outward manifestation (forum extranum/actus reus) of an opinion, judgment, or idea. Fourth, the scope of expression is broad. Freedom of expression includes the freedom to seek, receive, and transmit information or ideas, using oral, written, printed, or other media.

The three aforementioned court decisions that were used as the object of this study show that the judges did not seem to have given adequate consideration to the human rights aspects of the events. In the Prita Mulyasaris' case, the panel of judges tended to use formal considerations to release her from criminal sanction. The absence of government regulation as a derivative provision from the law is considered as a legal reason that the provisions in the law cannot be used to convict a case. This violates the principle of legality. However, it was not found whether Prita Mulyasaris' actions were protected by law as a form of consumer rights or, more broadly, as the right to freedom of expression. ${ }^{74}$ In the Prita Mulyasari's civil case, the main consideration of the panel of judges to release Mulyasari from the obligation to pay compensation filed by Plaintiff was that her complaint is in accordance with her feelings. The complaint was also sent personally via the personal email of some of her friends. In line with the verdicts of the criminal case, in the civil case, the panel of judges also seems to focus more on the formal aspects of the case..$^{75}$ In Budi Heryawan's case, legal considerations mainly focused on three aspects. First, the existence of the "palu arit" symbol is evidence that the defendant, as the person in charge/leader of the demonstration, had spread the teachings of communism and Marxism/Leninism. Second, the demonstration is justified by the Law Number 9 of 1998. However, the demonstration is considered against the law because it did not provide a written notification to the police. Third, the argument that Budi Heryawan is an environmental defender is considered inappropriate because according to the law, environmental defenders get legal protection when their struggle is conducted

\footnotetext{
Supreme Court Decisions Number 822K/Pid.Sus/2010 and Number 225PK/Pid.Sus/2011.

Supreme Court Decision Number 300K/Pdt/2010.
} 
under legal standards. Failure to provide written notification to the police during a demonstration is deemed no accordance with legal standards. Therefore, Budi Heryawan is not entitled to legal protection as referred to by the Law Number 32 of 2009 on Environmental Protection and Management. Based on the consideration, judges seem to use more formal legal arguments than the substance of the protection and respect for the right to freedom of expression as guaranteed in various legal instruments. ${ }^{76}$ In the case of Basuki Wasis, efforts to present a debate on human rights law were carried out by the advocate. The advocate built an argument that Basuki Wasis' action is a part of freedom of expression as regulated and guaranteed in various human rights instruments. The advocate also built an argument that the Law on Environmental Protection and Management protects Basuki Wasis.

The panel of judges, in their decision, seems to have chosen not to provide adequate arguments from the standpoint of human rights and the SLAPP. Judges almost never evaluate and respond to the human rights norms used by advocates The panel of judges rejected the plaintiff's claim using formal reasoning by stating that the experts' testimony has turned into the judges' legal opinion since it has been adopted in court decision. ${ }^{77}$

A big note from the three cases is that human rights law, particularly in regard to legal guarantees of the right to freedom of expression, has not received an adequate portion of consideration by the panel of judges. In addition to SLAPP, the lawsuits and criminal charge against these three persons also attempts to suppress/silence freedom of expression through a court mechanism (legal based).

The actions of Prita Mulyasari, Budi Heryawan, and Basuki Wasis can be categorized as freedom of expression. The complaint submitted by Prita Mulyasari to hospital management is that apart from being protected by human rights law, it is also protected by the health-related law and the consumer protection law. The human rights law and the Law on the Expression of Public Opinions protect the action of Budi Heryawan. Similarly, the Law protects Basuki Wasis who was present at the court to provide expert testimony. A person who is requested by the court to attend a trial has an obligation to attend. The criminal procedural law protects his presence. ${ }^{78} \mathrm{His}$ expertise, at the very least, is also expressly protected by human rights law, in particular Article 28F of the 1945 Constitution, Article 14 of the Law on Human Rights, Article 19 of the UDHR, and Article 19 of the ICCPR as ratified by the Law Number 11 of 2005.

According to the human rights law, if the judges do not agree that the act constitutes freedom of expression, the panel of judges must use the limitation clause of human rights as stipulated in Article 28J paragraph (2) of the 1945

\footnotetext{
Decision Number 559/Pid. B/2017/Pid. Byw and Surabaya High Court Decision Number 174/PID/2018/PT SBY. Decision Number 47/Pdt.G/2018/PN.Cbi.

Article 179 paragraph (1), Article 159 paragraph (2), Article 180 paragraph (1) of the Criminal Code and Article 35 of the Corruption Law.
} 
Constitution or Article 19 paragraph (3) of the ICCPR. Simply, freedom of expression is not a category of non-derogable rights. This means that freedom of expression can be limited. The question is how to legally restrict freedom of expression? Three conditions must be considered whether the limitation is based on law or not; Is the reason valid; and are these restrictions democratic?

Actions of the subjects of the study are lawful actions that not only do not violate the law but are also protected by law. Various legal rules provide guarantees for the expression of opinions carried out by the three people. The formal considerations used by the panel of judges will be more adequate and stronger if legal substance arguments are also used.

Reasons for the human rights limitation justified by human rights law are respect for the rights and freedoms of others, public order, public health, public morals, religious values, and national security. In the cases of Prita Mulyasari and Budi Wasis, the judges acquitted the two from both criminal charge and civil lawsuit. This ruling has shown that the judge, in extensive significance, provided guarantees to freedom of expression in both cases, although it did not explicitly consider human rights norms in their deliberations. In the Budi Heryawan case, substantively, if the panel of judges wants to punish Budi Heryawans' action, then it should be proven whether the act is proven to have violated the provisions regarding the aforementioned valid reasons or not. The panel of judges needs to examine one by one whether Budi Heryawans' action can be categorized as an action that injure the rights and freedom of other, public order, public health, public morals, religious values, and national security. Based on the case, Budi Heryawan is considered proven to have spread communism and Marxism-Leninism. However, in the evidence, it appears that the public prosecutor failed to prove that Budi Heryawan made the "palu arit" symbol. The prosecutor even said that an unknown person carried it out. Budi Heryawan is also considered to be the leader of the group of people who conducted the demonstration, therefore he is considered responsible for the demonstration. It is also evident that the demonstration was conducted without sending a written notification to the police. These considerations seem odd.

The laws protected the actions of Prita Mulyasari, Budi Heryawan, and Basuki Wasis. Therefore, the panel of judges should emphasize that the lawsuit and the charges against the three greatly disturb the democratic climate in Indonesia. Democracy assumes the existence of legal guarantees against criticism, oppositional actions, and expressions of citizens. To protect them, the court must stand to the point up that freedom of expression is a human right that is protected by law. Disturbance of enjoyment, whether perpetrated by individuals, groups including companies, and particularly the state, is a form of human rights violation and/or abuses. 


\section{E. Conclusion}

This study concludes two points. First, there are three patterns of SLAPP in Indonesia. They are (1) the use of SLAPP to the people who fight for their human rights; (2) the use of SLAPP to the people who defend their rights against human rights violations committed by the state or human rights abuses committed by third parties such as corporation; and (3) the use of SLAPP to experts whose testimonies are used by the court. Portraits of SLAPP in Indonesia can be grouped into four groups; SLAPP is an attempt to shift problems from perpetrators to victims, SLAPP puts the victims in a high-risk position, SLAPP drains and distracts the victim, and SLAPP postponed the resolution of the main problems.

Second, SLAPP is an act that contradicts and/or has an adverse impact on freedom of expression. Various human rights legal instruments, in both national and international levels, regulate and guarantee freedom of expression. Courts must be present to affirm that the state takes sides in protecting freedom of expression. This affirmation needs to be realized in the form of decision that protect everyone who experiences a SLAPP in both criminal and civil mechanisms.

\section{References}

\section{Books}

Alexander, Larry, Is There a Right of Freedom of Expression, Cambridge University Press, Cambridge, 2005.

Carlsson, Ulla and David Goldberg, The Legacy of Peter Forsskal. 250 Years of Freedom of Expression, Nordicom, Sweden, 2017.

Fenwick, Helen, Civil Liberties and Human Rights $4^{\text {th }}$ Edition, Routledge-Cavendish, Oxon, 2007.

Golash, Deirdre, Freedom of Expression in a Diverse World, Springer, New York, 2010.

Howard, Erica, Freedom of Expression and Religious Hate Speech in Europe, Routledge, New York, 2018.

Kaelan, Filsafat Pancasila, Pandangan Hidup Bangsa Indonesia, Paradigma, Yogyakarta, 2002.

Melkonian, Harry, Freedom of Speech and Society, Cambria Press, New York, 2012.

Moon, Richard, The Constitutional Protection of Freedom of Expression, University of Toronto Press, Toronto, 2000.

O'Rourke, K.C. and John Stuart Mill and Freedom of Expression. The Genesis of a Theory, Taylor \& Francis e-Library, London and New York, 2003.

Eko Riyadi, Hukum Hak Asasi Manusia. Perspektif Internasional, Regional, dan Nasional, PT Raja Grafindo Persada, Jakarta, 2018.

Stuart, John, On Liberty, The Floating Press, 2009.

\section{Other Documents}

Barak, Aharon, "Freedom of Expression and Its Limitation", Qasher, Issue 8, 1990. 
Barker, John C,. "Common-Law and Statutory Solutions to the Problem of SLAPPs", Loyola of Los Angeles Law Review, Vol. 26, Issue 395, 1993.

Brink, David, "Mill's Deliberative Utilitarianism”, Philosophy \& Public Affairs, Vol. 21, Issue 1, 1992.

Business \& Human Rights Resource Center, "Strategic Lawsuits against Publik Participation: Southeast Asia Cases \& Recommendations for Governments, Business, \& Civil Society", Briefing Note, 2020.

Canan, Penelope and George W. Pring, "Studying Strategic Lawsuit against Public Participation: Mixing Qualitative and Quantitative Approaches", Law \& Society Review, Vol. 22, Issue 2, 1988.

Cosentino, Victor J., "Strategic Lawsuits against Public Participation: An Analysis of the Solutions", California Western Law Review, Vol. 27, Issue 2, 1991.

Forsskal, Peter, "Thoughts on Civil Liberty," paragraph 21, http://www.peterforsskal.com/thetext.html.

Grossman, Claudio, "Challenges to Freedom of Expression Within the InterAmerican System: A Jurisprudential Analysis", Human Rights Quarterly, Vol. 34, Issue 2, 2012.

H. Loewy, Arnold, "Freedom of Speech as a Product of Democracy", University of Richmond Law Review, Vol. 27, Issue 3, 1993.

Kulk, Stefan and Frederik Zuiderveen Borgesius, "Google Spain v. Gonzalez: Did the Court Forget about Freedom of Expression?", European Journal of Risk Regulation, Vol. 5, Issue 3, 2014.

Lembaga Studi dan Advokasi Masyarakat, "Palu Hakim Kasus Saiful Mahdi: Sinyal Buruk bagi Kebebasab Berekspresi dan Berpendapat di Indonesia", Press Release, 2020, https://elsam.or.id/palu-hakim-kasus-saiful-mahdi-sinyal-burukbagi-kebebasan-berekspresi-dan-berpendapat-di-indonesia/.

McBrayer, Lauren, "The DirecTV Cases: Applying anti-SLAPP Laws to Copyright Protection Cease-and-Desist Letters", Berkeley Technology Law Journal, Vol. 20, Issue 2, 2005.

Mowrer, J. Reid, "Protection of the Public Against Litigious Suits ("PPALS"): Using 1993 Federal Rule 11 to Turn SLAPPs Around", Natural Resources Journal, Vol. 38, Issue 3, 1998.

Pring, George, "SLAPPs: Strategic Lawsuits against Public Participation", Pace Environmental Law Review, Vol.7, Issue 1, 1989.

Quinlan, Colin, "Erie and the First Amendment: State Anti-SLAPP Laws in Federal Court after Shady Grove", Columbia Law Review, Vol. 114, Issue 2, 2014.

Richards, Robert D., "A SLAPP in the Facebook: Assessing the Impact of SLAPP on Social Network, Blogs and Consumer Gripe Sites", DePaul Journal of Art, Technology \& Intellectual Property Law, Vol. 21, Issue 2, 2011.

Riordan, Patrick, "Freedom of Expression, No Matter What?", Studies: An Irish Quarterly Review, Vol. 105, Issue 418, 2016. 
Safenet Voice, "SAFEnet: Putusan Bersalah pada Saiful Mahdi Meruntuhkan Bangunan Kebebasan Akademik", Press Release, 2020, https://id.safenet.or.id/2020/04/rilis-pers-safenet-putusan-bersalah-padasaiful-mahdi-meruntuhkan-bangunan-kebebasan-akademik/.

Sahid Hadi, "Bintang Emon is Getting SLAPP-ed", Kolom, CNN Indonesia, June 19, 2020, https://www.cnnindonesia.com/nasional/20200619113234-13515121/bintang-emon-is-getting-slapp-ed.

Saner, Katelyn E., "Getting SLAPP-ed in Federal Court: Applying State Anti-SLAPP Special Motions to Dismiss in Federal Court After 'Shady Grove"', Duke Law Journal, Vol. 63, Issue 3, 2013.

Scanlon, Thomas, "A Theory of Freedom of Expression", Philosophy \& Public Affairs, Vol. 1, Issue 2, 1972.

The Economist, "Democracy Index 2019. A year of democratic seatbacks and popular protest", A Report by The Economist Intelligence Unit.

Wilson, Paul D., "Of Sexy Phone Calls and Well-Aimed Goal Balls: Anti-SLAPP Statutes in Recent Land-Use Damages Litigation", The Urban Lawyer, Vol. 36, Issue 2, 2004.

World Justice Project, "Rule of Law Index 2020", Annual Report. , "Rule of Law Index 2019", Annual Report. "Rule of Law Index 2018-2017", Annual Report. "Rule of Law Index 2016", Annual Report. "Rule of Law Index 2014", Annual Report.

\section{Legal Documents}

1945 Constitution of the Republic of Indonesia [Undang-Undang Dasar Negara Republik Indonesia Tahun 1945].

Law Number 9 of 1998 on Freedom of Expressing Opinions in Public [UndangUndang Nomor 9 Tahun 1998 tentang Kemerdekaan Menyampaikan Pendapat di Muka Umum].

Law Number 39 of 1999 on Human Rights [Undang-Undang Nomor 39 Tahun 1999 tentang Hak Asasi Manusia].

Universal Declaration of Human Rights.

Law Number 12 of 2005 on the Ratification of the International Covenant on Civil and Political Rights [Undang-Undang Nomor 12 Tahun 2005 tentang Pengesahan International Covenant on Civil and Political Rights].

Supreme Court Decision Number 822K/Pid.Sus/2010 [Putusan Mahkamah Agung Nomor 822K/Pid.Sus/2010].

Supreme Court Decision Number 225PK/Pid.Sus/2011 [Putusan Mahkamah Agung Nomor 225PK/Pid.Sus/ 2011].

Supreme Court Decision Number 300K/Pdt/2010 [Putusan Mahkamah Agung Nomor 300K/Pdt/2010]. 
Decision Number 559/Pid. B/2017/Pid. Byw [Putusan Nomor 559/Pid. B/2017/Pid. Byw].

Surabaya High Court Decision Number 174/PID/2018/PT SBY [Putusan Pengadilan Tinggi Surabaya Nomor 174/PID/2018/PT SBY].

Decision Number 47/Pdt.G/2018/PN.Cbi [Putusan Nomor 47/Pdt.G/2018/PN.Cbi].

Decision Number 123/Pid.Sus-TPK/017/PN. Jkt. Pst [Putusan Nomor 123/Pid.SusTPK/017/PN Jkt.Pst].

Decision Number 1269/PID.B/2009/PN.TNG. [Putusan Nomor

1269/PID.B/2009/PN.TNG]. 